\title{
GGE BIPLOT ANALYSIS FOR YIELD PERFORMANCE OF GRAIN AMARANTH GENOTYPES ACROSS DIFFERENT ENVIRONMENTS IN WESTERN INDIA
}

\author{
Nalin Pagi $^{1}{ }^{*}$, Nitin Prajapati ${ }^{2}$, Karen Pachchigar ${ }^{3}$, Darshan Dharajiya ${ }^{3}$, S. D. Solanki ${ }^{1}$, Nishit Soni ${ }^{1}$, \\ Pranay Patel ${ }^{1}$
}

${ }^{1}$ Department of Genetics and Plant Breeding, C. P. College of Agriculture, S. D. Agricultural University, Sardarkrushinagar - 385506, Gujarat, India.
${ }^{2}$ Centre for Crop Improvement, S. D. Agricultural University, Sardarkrushinagar - 385506, Gujarat, India.
${ }^{3}$ Department of Plant Molecular Biology and Biotechnology, C. P. College of Agriculture, S. D. Agricultural University, Sardarkrushinagar - 385506, Gujarat, India

Received - April 17, 2017; Revision - May 23, 2017; Accepted - June 12, 2017 Available

Available Online - June 30, 2017

http://dx.doi.org/10.18006/2017.5(3).368.376

\section{KEYWORDS}

GGE biplot

Grain amaranths

Grain yield

What-won-where

\begin{abstract}
Stable performance of grain amaranths genotypes at specific environment is critical for obtaining high and consistent yield. This study was conducted to assess grain yield stability of thirteen genotypes in varied environments in three successive growing seasons and effects of genotype $(\mathrm{G})$ and genotypexenvironment (GE) interaction were illustrate graphically based on "what-won-where" to advocate genotypes for a specific environment, using GGE biplot. Result of study revealed that GGE biplot was effective to recognize stable and highest yield (1648.92 kg/ha) genotype as $G_{5}$ followed by $G_{6}(1457.24 \mathrm{~kg} / \mathrm{ha})$ and $\mathrm{G}_{3}(1268.62 \mathrm{~kg} / \mathrm{ha})$ genotypes while the genotype $\mathrm{G}_{7}$ had the lowest grain yield and was the least stable across varying environments. This study could be aid tool for endorsement of amaranths genotypes for specific environment, taking into elucidation the peculiarities of genotypes and growing stipulation.
\end{abstract}

* Corresponding author

E-mail: nalinpagi2007@gmail.com (Nalin Pagi)

Peer review under responsibility of Journal of Experimental Biology and Agricultural Sciences.

Production and Hosting by Horizon Publisher India [HPI] (http://www.horizonpublisherindia.in/).

All rights reserved.
All the article published by Journal of Experimental Biology and Agricultural Sciences is licensed under a Creative Commons Attribution-NonCommercial 4.0 International License Based on a work at www.jebas.org.

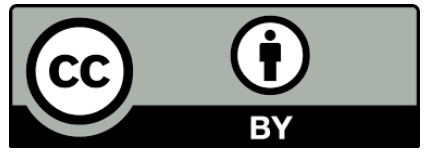




\section{Introduction}

Grain amaranth belong to the genus Amaranthus is one of the astounding underutilized pseudoceral with rich nutritional diet profile and seldom utilized as used as food grain, leafy vegetables, forage and ornamentals for long. It includes approximately 60 species (Sauer, 1967), of them five major species considered for grain production of grain type Amaranth viz., A. hypochondriacus L. $(2 \mathrm{n}=32)$, A. cruentus $(2 \mathrm{n}=34)$, A. caudatus $\mathrm{L} .(2 \mathrm{n}=32$ and occasionally $2 \mathrm{n}=34$ also), A. adulis Spegazzini $(2 \mathrm{n}=32)$ and $A$. tricolor $(2 \mathrm{n}=34)$ (Patel et al., 2014). Grain amaranths is rich in "Protein complements" with higher lysine content than other cereal grains which offers remarkable opportunity to exploit grain amaranth (Bressani, 1989). It has been well reported that amaranth leaves are excellent sources of protein, with its maximum accumulation in the blossoming phase (Kadoshnikov et al., 2005). Therefore, it is a good diet supplement to pulses for sulphur rich amino acid. Crop is widely spread over Asia with astounding genetic and morphological diversity and nutritional pool, nevertheless crop breeding program have given little attention over genetic improvement of this "alternative crop".

The aptness to develop prominent high yielder and stable genotypes over wide environment is an unambiguous motto in pragmatic plant breeding programme (Boshev et al., 2014). Assorted environments can diminish the steadiness of plant varieties (Hebert et al., 1995). Genotype $\times$ environment interaction (GE) have shown there supremeness for delineating stability of genotypes and have partitioned variation that better aid for selection of consistent stable genotypes in many different studies (Dehghani et al., 2006; Yan et al., 2007; Sabaghnia \& Sabaghpour, 2008). There are several methods for stability analysis among which GGE biplot analysis was used in the present study to deduce stability of the crop with aim to investigate the stability of seed yield in amaranths and graphically summarize and considerate the assets of G and GE interaction (Yan \& Kang, 2003; Samonte et al., 2005; Dehghani et al., 2009, Balestre et al., 2009; Oliveira et al., 2010; Tonk et al., 2011).

Present study was undertaken for the first time to gather information about GE interaction of different amaranth genotypes for high seed yield using three year data using GGE biplot analysis.

\section{Materials And Methods}

2.1 Experimental site and materials

The experiment was carried out at the Crop Improvement Research Station $\left(24^{\circ} 12^{\prime} \mathrm{N}, 7^{\circ} 12^{\prime} \mathrm{E}\right.$ and $\left.154.5 \mathrm{~m}\right)$, Sardarkrushinagar Dantiwada Agricultural University, Sardarkrushinagar, Gujarat, India. Thirteen genotypes viz., Annpurna, Durga, BGA-2, GA-1, GA-2, GA-3, PRA-1, PRA-2, PRA-3, RMA-4, RMA-7, Suvarna and VL-344 from diverse backgrounds were sown in randomized block design (RBD) design with three replications in six rows of 4 meter length with $45 \times 15 \mathrm{~cm}$ spacing for each genotype. All the genotypes were grown during the Rabi season in 2012-13, 2013-14 and 2014-15 to access their stability for grain yield across variable environments. The size of unit plot was $4.0 \times 1.8 \mathrm{msq}$. Plots were thinned duly ensuring a single plant per hill. Two rows of each plot were harvested at maturity, siliquae were shelled, dried out and grain yield was measured in each plot.

2.2 Statistical analysis

Statistical computations and estimations were carried out using INDOSTAT software. Analysis of variance was carried out to partition the variation due to genotypes, environment and GE interaction. Stability analysis of data was carried out by employing Eberhart \& Russell model (1966). The untransformed data of each genotype from field trials were subjected to $\mathrm{G} \times \mathrm{E}$ biplot analysis for deduction of GE interaction using PBTools software version 1.4 (PBTools, 2014). The GGE biplot is a multi-faceted most comprehensive tool and produce lucrative informative graphs depicting (i) "what-won-where" pattern, (ii) ranking of amaranths genotypes with respect to yield and stability, (iii) environment vectors, and (iv) assessment of environment to ideal environment (Yan \& Kang, 2003). The GGE biplot study execute by using singular value decomposition (SVD) model that presents the first two principal components ( $\mathrm{PC} 1$ and $\mathrm{PC} 2$, referred as primary and secondary effects, respectively) resulting from environment centered yield data (yield discrepancy due to GGE) based on symmetric scaling $\mathrm{f}=0.5$ (Yan et al., 2000). Each environment is characterized by its vector (the line that connects it with the origin of the biplot), the length of the vector was used to determine the discriminating ability of each of the test environments, with a shorter vector implying that the environment was not well represented by PC1 and PC2 (Yan et al., 2007). The angle between environments vectors were used to judge correlations (similarities/dissimilarities) between pairs of environments (Yan \& Kang, 2002).

\section{Results and Discussion}

Development of a stable variety is one of the major goals for all breeding programme because phenotypically stable genotypes are usually required for commercial production of crop plants. Hence, to find out stable genotypes for different characters, stability analysis was employed as suggested by Eberhart \& Russell (1966) was employed. Accordingly, three kinds of linear responses (bi) $v i z ., b i<1, b i=1$ and $b i>1$ have been considered in which $b i=1$ is average stability and widely adaptable to different environments; bi $>1$ is below average stability, increasing sensitivity to environmental changes and well adapted to favourable environment and $\mathrm{bi}<1$, above average stability, greater tolerance to environmental changes; thereby genotypes would have the specific adaptability to poor yielding environment.

Based on ANOVA it was concluded that all the thirteen amaranth genotypes significantly differed from each other indicating the presence of substantial variation among them (Table 1). Further, the performance of all the genotypes varied under all the environments and it is depicted in figure 1. Based on mean yield data, each genotype was ranked which is given in table 2 . 


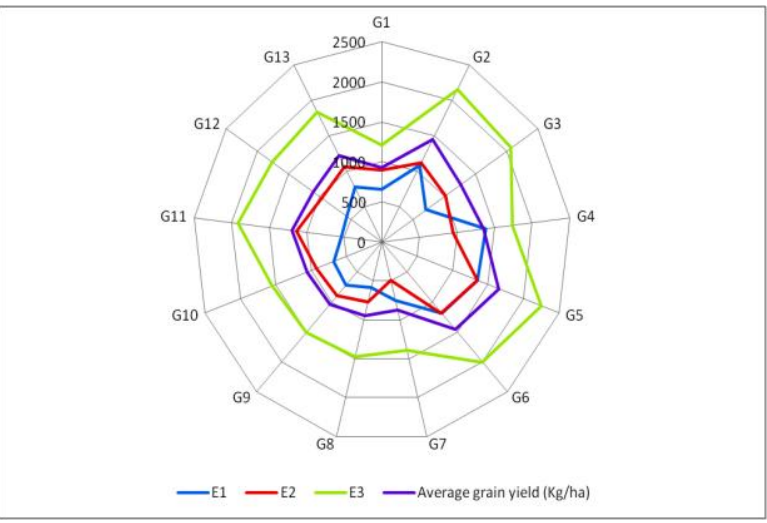

Figure 1Yield performance of different amaranth genotypes across three environments
The set of thirteen genotypes was evaluated under three environments. The data of analysis of variance for different characters are presented in table 1 . The $\mathrm{G} \times \mathrm{E}$ interaction was found significant for all the characters except for inflorescence length, which revealed that genotypes interacted differently with environmental variations for days to flowering, days to maturity, plant height, test weight, inflorescence length, plant stand at harvesting, fodder yield and grain yield characters. The variances due to $G \times E$ were further partitioned into components, (i) $G \times E$ (linear) and (ii) $\mathrm{G} \times \mathrm{E}$ (non-linear) i.e., pooled deviation. Pooled deviation, the non-linear component of $\mathrm{G} \times \mathrm{E}$ interaction was observed significant for the traits, days to flowering, days to maturity, plant height, test weight, inflorescence length and grain yield, whereas plant stand at harvesting and fodder yield were

Table 1 Analysis of variance (mean squares) for stability pertaining to various characters in amaranth genotypes

\begin{tabular}{|c|c|c|c|c|c|c|c|c|c|}
\hline \multicolumn{10}{|c|}{ Characters } \\
\hline Source of variation & $\begin{array}{l}\text { Degree of } \\
\text { Freedom }\end{array}$ & $\begin{array}{l}\text { Days to } \\
\text { flowering }\end{array}$ & $\begin{array}{l}\text { Days to } \\
\text { maturity }\end{array}$ & Plant height & $\begin{array}{c}\text { Test } \\
\text { Weight } \\
(10 \mathrm{ml} / \mathrm{g})\end{array}$ & $\begin{array}{l}\text { Inflorescence } \\
\text { Length }(\mathbf{c m})\end{array}$ & $\begin{array}{l}\text { Plant stand } \\
\text { at } \\
\text { harvesting }\end{array}$ & $\begin{array}{c}\text { Fodder yield } \\
\text { (kg/plot) }\end{array}$ & $\begin{array}{l}\text { Grain yield } \\
\text { (kg/plot) }\end{array}$ \\
\hline Genotypes (G) & 12 & $432.66^{* * *}$ & $238.22 * *$ & $3,756.04 * *$ & 0.01 & $418.64 * *$ & 143.90 & $3,770,923 * *$ & $165,246^{* * *}$ \\
\hline Environments (E) & 2 & $555.52 * *$ & $248.23 * *$ & $6,239.14 * *$ & $0.39 * *$ & $2101.35^{* *}$ & $4177.14 * *$ & $229,989,508^{* *}$ & $3,152,549 * *$ \\
\hline $\mathbf{G} \times \mathbf{E}$ & 24 & $8.66^{*}$ & $7.20^{*}$ & $122.72 * *$ & $0.01^{*}$ & 81.03 & $123.15^{* *}$ & $1,335,427 * *$ & $334,988 * *$ \\
\hline Environment (Linear) & 1 & $1111.05^{* *}$ & $496.45^{* *}$ & $12,478.29 * *$ & 0.77 & $4202.69 * *$ & $8354.28 * *$ & $459,979,017 * *$ & $6,305,098^{* *}$ \\
\hline G x E (Linear) & 12 & $15.81 * *$ & $11.23^{* *}$ & 154.31 & $0.01 * *$ & $145.60 * *$ & $245.20 * *$ & $2,348,038^{* *}$ & $34,541^{*}$ \\
\hline Pooled deviation & 13 & $1.40 * *$ & $2.92 *$ & $84.12 * *$ & $0.01 * *$ & $15.20 * *$ & 1.01 & 297,984 & $30,863 *$ \\
\hline Pooled error & 72 & 1.32 & 1.08 & 11.42 & 0.01 & 6.89 & 160.66 & 686,233 & 48,935 \\
\hline
\end{tabular}

*, ** Significance at 5 and 1 per cent probability levels, respectively

Table 2 Mean grain yield $(\mathrm{Kg} / \mathrm{ha})$ of thirteen amaranth genotypes across three environments at $\mathrm{E}_{1}, \mathrm{E}_{2}$ and $\mathrm{E}_{3}$ their average seed yield

\begin{tabular}{|c|c|c|c|c|c|c|}
\hline Name of genotype & Genotype code & E1 & E2 & $\mathbf{E 3}$ & Average grain yield (Kg/ha) & Rank \\
\hline Annpurna & G1 & 658.40 & 902.72 & 1212.04 & 924.39 & 12 \\
\hline Durga & G2 & 1078.13 & 1120.30 & 2148.77 & 1449.07 & 3 \\
\hline BGA-2 & G3 & 710.25 & 1023.08 & 2072.53 & 1268.62 & 5 \\
\hline GA-1 & G4 & 1382.64 & 944.38 & 1736.73 & 1354.58 & 4 \\
\hline GA-2 & G5 & 1351.78 & 1347.14 & 2247.84 & 1648.92 & 1 \\
\hline GA-3 & G6 & 1189.24 & 1182.79 & 1999.69 & 1457.24 & 2 \\
\hline PRA-1 & G7 & 754.28 & 490.71 & 1390.43 & 878.47 & 13 \\
\hline PRA-2 & G8 & 588.45 & 773.10 & 1477.78 & 946.44 & 11 \\
\hline PRA-3 & G9 & 711.90 & 892.54 & 1507.72 & 1037.39 & 10 \\
\hline RMA-4 & G10 & 684.32 & 923.55 & 1549.69 & 1052.52 & 9 \\
\hline RMA-7 & G11 & 537.83 & 1138.82 & 1918.83 & 1198.49 & 7 \\
\hline Suvarna & G12 & 563.34 & 969.85 & 1758.95 & 1097.38 & 8 \\
\hline VL-344 & G13 & 771.56 & 1064.75 & 1836.11 & 1224.14 & 6 \\
\hline
\end{tabular}

Journal of Experimental Biology and Agriculture Science http://www.jebas.org 
unpredictable due to non significant of pooled deviation as well as lower magnitude than linear component. The non-linear effect must be significant and oflower magnitude than linear component to predict the performance of genotype and its stability. This reflected greater importance of linear portion in building up total $\mathrm{G}$ $\times \mathrm{E}$ and the possibility of prediction across the environments for these characters. The seasonal variation in these characters may be due to micro-environmental conditions i.e., differences in climatic or soil factors among environments, during the grain filling stage. The variation in meteorological parameters viz., temperature $\left({ }^{\circ} \mathrm{C}\right)$ and relative humidity $(\%)$ are represented in figure 2 . The genotypes $\times$ environment interaction was highly significant for mean grain yield, which revealed that genotypes interacted differently with environmental variations in character.

On analyzing SVD based GGE biplot analysis, the GGE biplot revealed that component $\mathrm{PC} 1=73.6 \%$ and $\mathrm{PC} 2=21.5 \%$ explaining total 85 percent of environmental centred variation of mean grain yield. The observed high magnitude of $\mathrm{G} \times \mathrm{E}$ (linear) component could lead to the identification of genotypes adapted to different environmental conditions on the basis of deviation from the regression line of unit slope (Figure 3).

\subsection{What-won-where Biplot for vertex/ideal genotype}

The biplot (Figure 3) represents a polygon, where some of the genotypes were placed on the crests, while the rest were surrounded by the polygon. As the genotypes placed on the peak had the longest detachment from the biplot origin and they were expected to be the most responsive. The genotypes at the crests of the polygon could be called the vertex/ideal genotype.

In present study, the genotypes $\mathrm{G}_{4}$ in $\mathrm{E}_{1}$ are the vertex genotype, which had the highest grain yield. The two environments $\left(E_{2}\right.$ and $E_{3}$ ) were to be found in the same sector on the graph, which recommended that these environments did not differ significantly among themselves. The genotype $\mathrm{G}_{5}$ is the only apex genotype for environment $E_{2}$ and $E_{3}$ environments. None of the environments fell in the sectors with genotypes, $G_{1}, G_{7}, G_{9}$ and $G_{11}$, representing that these genotypes were not appropriate for growing in these environments.

In an "ideal" view (Figure 4), it was observed that the genotype $\mathrm{G}_{5}$ (1648.92) was in close proximity to the ideal genotype, followed by $\mathrm{G}_{6}(1457.24 \mathrm{Kg} / \mathrm{ha})$ and $\mathrm{G}_{4}(1354.58 \mathrm{Kg} / \mathrm{ha})$, respectively. According to Yan \& Kang (2003), a model genotype could be described as one which was the uppermost yielding across tested environments and is utterly stable in its performance.

\subsection{Average yield and stability of genotypes}

The average grain yield and stability of the genotypes presented in Figure 4. The AEAaxis (average environmental axis, AEA) passes across the biplot origin. The point of average environment coordinates for environments was indicated by open blue circle with an arrow. An "ideal" genotype was represented by closed blue dot in Figure 4. The higher yielding genotypes located closer to the circle; the stable genotypes are lie on the upper area of the line, and unstable are those in the lower fraction of the biplot. Considering

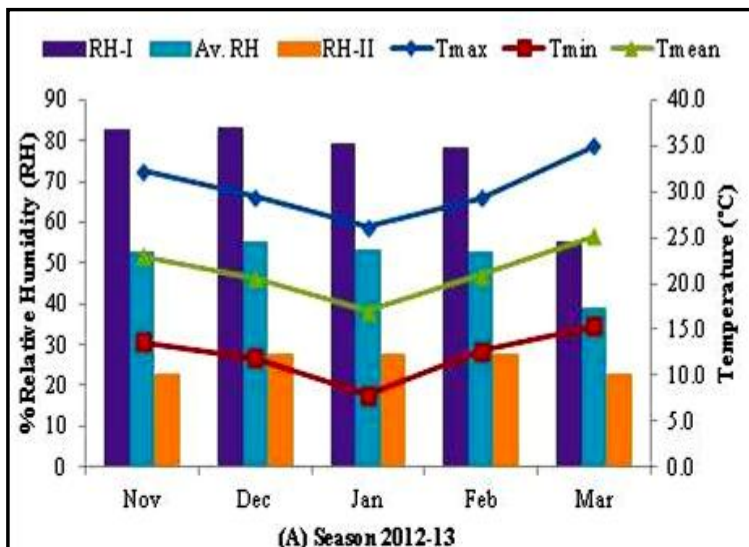

(A) Season 2012-13
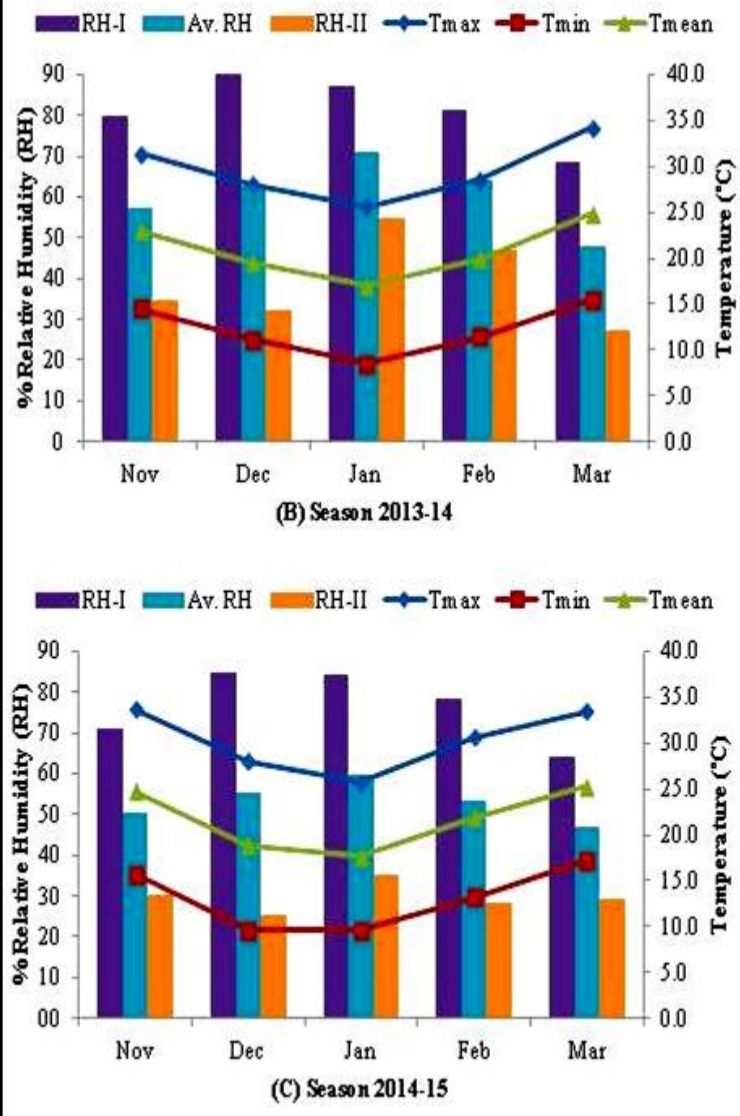

Figure 2 Meteorological parameters of three environments (RH-1 Relative Humidity at 0700 LMT, RH-2: Relative Humidity at 0700 LMT, Av. RH: Average Relative Humidity, $\mathrm{T}_{\max }$ : Maximum Temperature, $\mathrm{T}_{\min }$ : Minimum Temperature, $\mathrm{T}_{\text {mean }}$ : Average Temperature) 


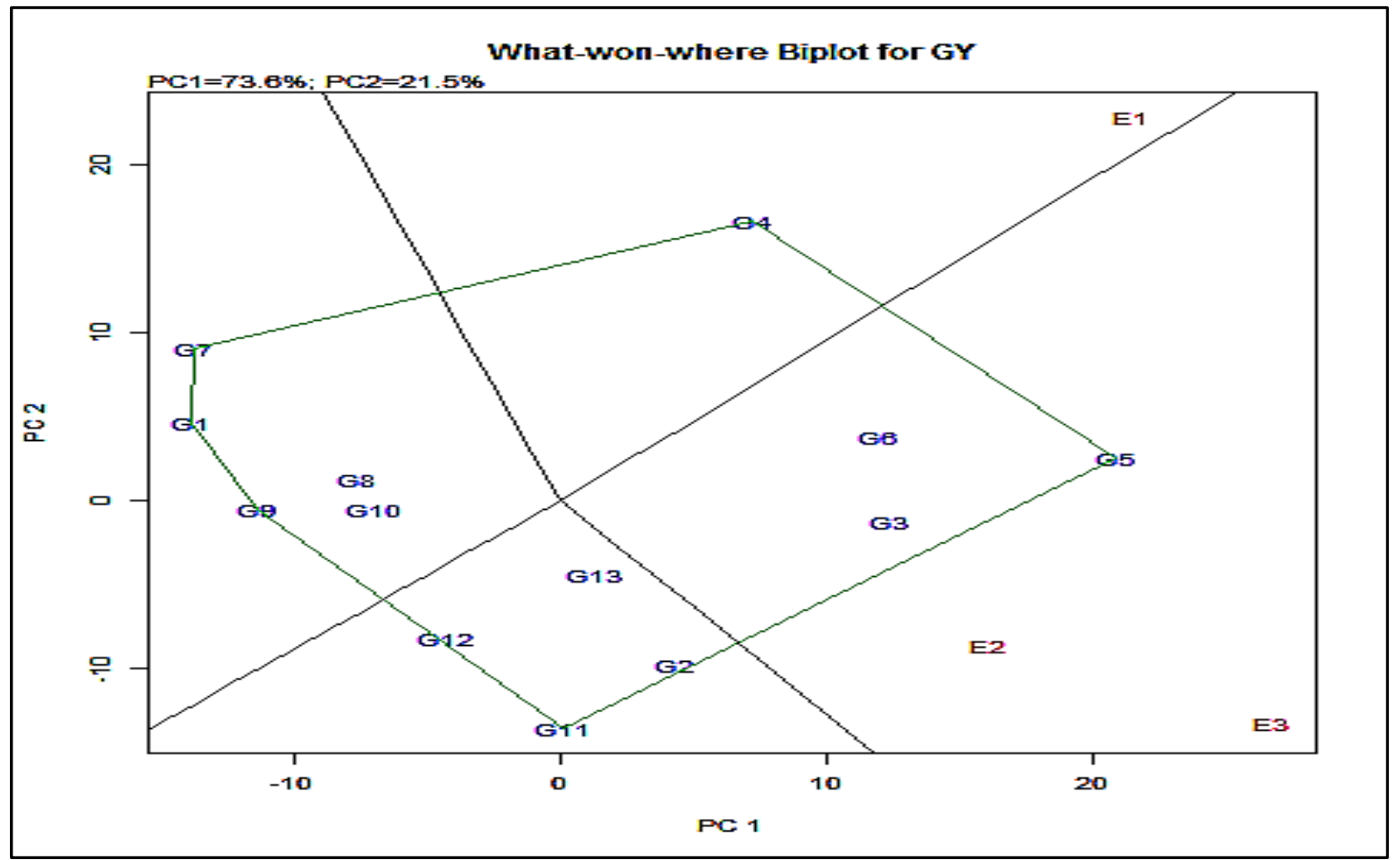

Figure 3 A genotype + (genotype $\times$ environment) interaction biplot showing genotype performance in each environment.

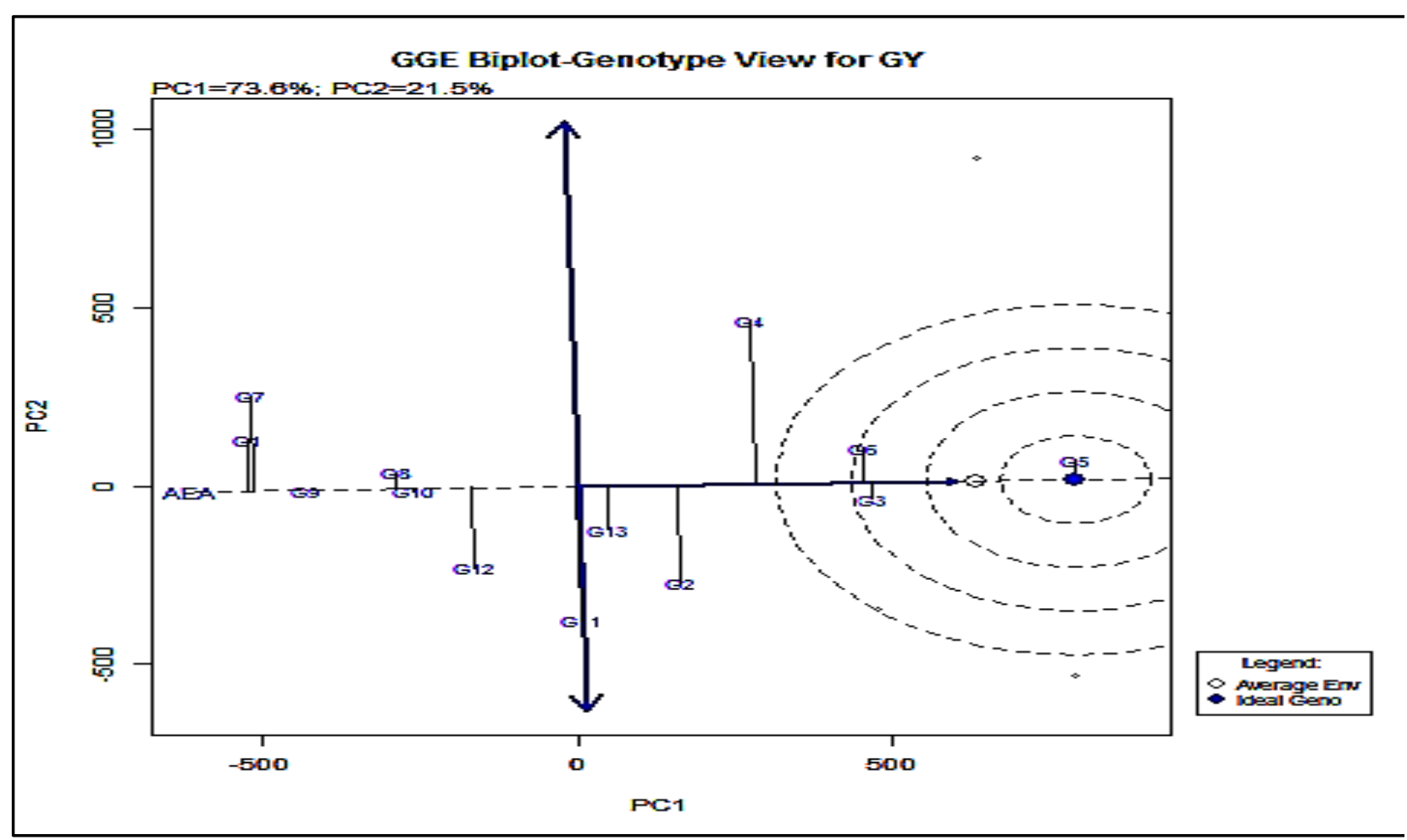

Figure 4 Comparison of genotypes with the ideal genotype showing the environmental axis (AEA) the GGE biplot. Environments and genotypes are denoted by 'E' and 'G', respectively. AXIS1 and AXIS2 are the first and second principal components, respectively.

Journal of Experimental Biology and Agriculture Science http://www.jebas.org 
this, the highest projection on the performance line holding by genotype $\mathrm{G}_{5}$ has the highest average grain yield $(1648.92 \mathrm{Kg} / \mathrm{ha})$, followed by $\mathrm{G}_{6}(1457.24 \mathrm{Kg} / \mathrm{ha})$ and $\mathrm{G}_{4}(1354.58 \mathrm{Kg} / \mathrm{ha})$ which are positioned very close to the genotype $\mathrm{G}_{5}$ (Figure 4 ).

\subsection{Environment evaluation based on GGE biplot}

The cosines of the angle between parents were used for the analysis of the interrelationship between entries / testers:

$\cos \left[a_{i j}\right]=r_{i j}$

Where, $a_{i j}$ is the angle between environments $i$ and environments $j$ and $r_{i j}$ is the correlation coefficient between both the environments.

If the angle between their vectors is $<90^{\circ}$ considering the two environments are positively correlated, if the angle is $>90^{\circ}$ they are negatively correlated, and independent if the angle between them is $90^{\circ}$. The angle of $0^{\circ}$ specifies that the correlation $[r]$ is 1 and the angle of $180^{\circ}$ represents that the correlation is -1 . The more discriminating entries exist testers with longer vectors, while less discriminating has short vectors and those position at the biplot origin are not discriminating Rastogi et al. (2011).

The environments were presented in Figure 5 has discriminating ability and representativeness. The representative environment of all other environments has longest distance between the marker of the environment to the biplot origin, is a measure of its discriminating ability considered as ideal environment, that is most discriminating for genotypes and shortest projection from the marker of location onto the AEA Y-axis is the measurement of its representativeness (Yan, 2001; Yan \& Kang, 2003).

Considering this, $E_{3}$, as it is, as $E_{3}$ is far away from the plot origin and had the shortest projection onto AEA Y-axis was the most discriminating as well as the most typical environment, respectively. The other favorable environment $\mathrm{E}_{2}$ was positioned close to $\mathrm{E}_{3}$, which indicates that stable production of amaranths is possible in this environment. The pattern of environments on the biplots suggested that all the environments were positioned in different concentric circle (Figure 5). In present study, as the angle between $E_{2}$ and $E_{3}$ environments was less than $90^{\circ}$, it revealed that $\mathrm{G} \times \mathrm{E}$ was moderately small and these environments tend to discriminate among genotypes in a similar manner and have a strong relationship.Corresponding environments were considered as the best environments for genetic discrepancy of genotypes under study (Tonk et al., 2011; Miah et al., 2015). Besides, the environment which is not far away from the origin of biplot did not have the discriminating ability and was not illustrative $\left(E_{1}\right)$, as the AEA Y-axis shown large projection (Figure5).

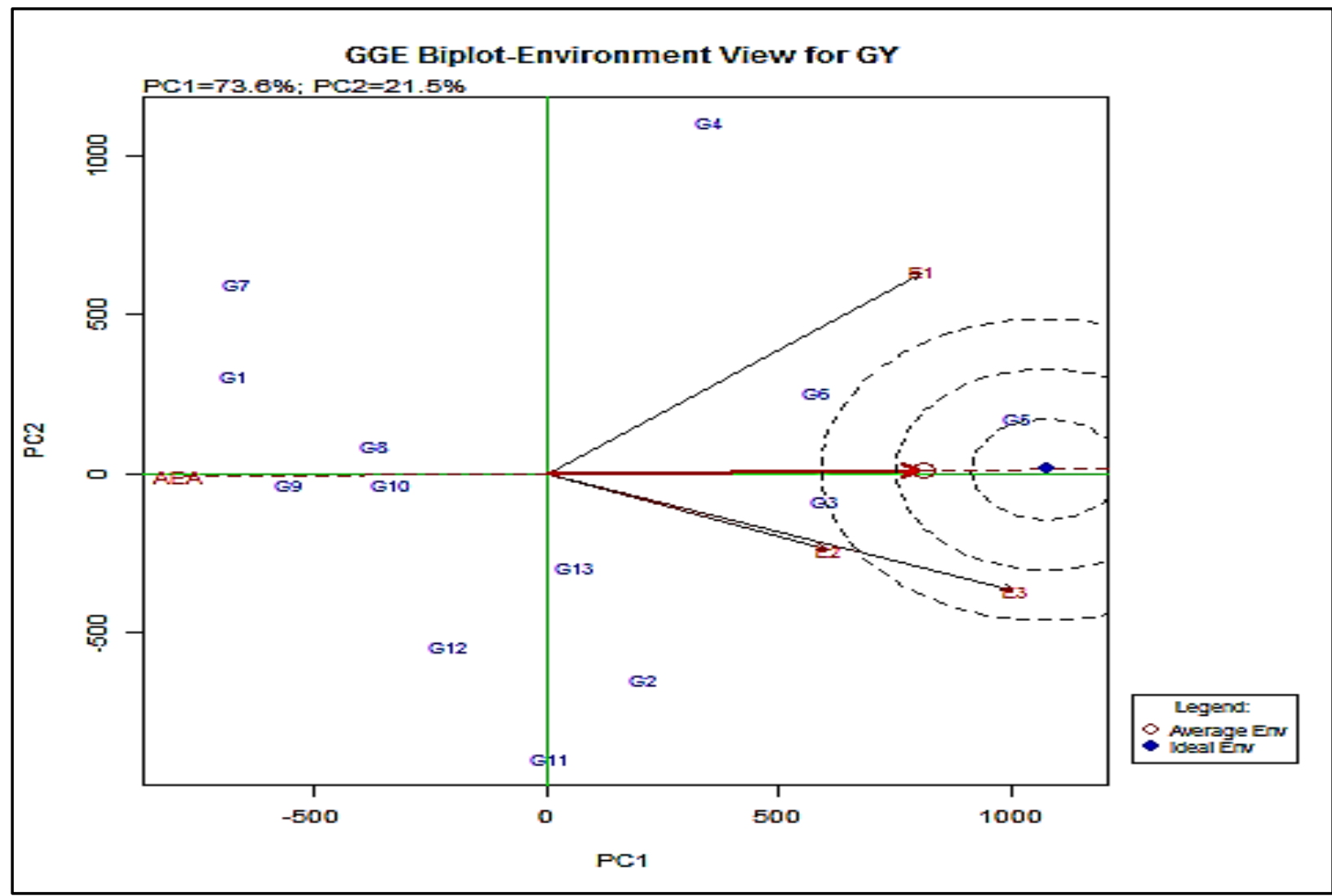

Figure 5 Comparison of environments with an ideal environment. The genotypes and environments are indicated by $G$ and $E$, respectively. 


\subsection{Relationship among the environments}

The correlation between the test environments is represents by the vectors of all three environments that facilitating the determination of the relationship between environments (Figure 6).In biplot environment view, the vectors of three environments depicting the relationship between environments while cosine of the angle between two environments shows the relationship among them (Yan, 2001). Both, $\mathrm{E}_{1}$ and $\mathrm{E}_{3}$ had the longer vectors thus, they were the best for genetic discrimination of genotypes but on considering the angle between these two environments they are comparatively less discriminating than $E_{2}$. The environment $E_{2}$ was the least representative environment in this investigation because it has shorter vector. Minimum angle between the vectors of $E_{1}$ and $\mathrm{E}_{2}$ has shown that they had robust correlation.

An essential target in a breeding program is to accommodate authentic indication that will gratify as a guide for selection of the best genotypes that have to be planted in the following seasons and to be capable to forecast yield as exactly as possible based on limited experimental data. The objective of any breeding experiment is to put up authentic clue that will gratify as a guide for selection of the model genotypes and ability for projection of yield as exactly as likely based on restricted experimental data. The amaranth genotypes effectively identified by means of GGE biplot which should be considered for growing in $\mathrm{E}_{2}$. Moreover, by means of this method, it was apparently established that high and stable yields could be attained only in specific environment. Other researchers observed that GGE biplot analysis is a suitable device for detecting experimental environments to select best genotypes in field crops as well (Balestre et al., 2009; Ilker et al., 2009; Oliveira et al., 2010; Tonk et al., 2011; Khalil et al., 2011; Beyene et al., 2011, Nzuve et al., 2013; Mortazavian et al., 2014; Miah et al., 2015).

\section{Conclusion}

In the present study, the genotypes $\mathrm{G}_{4}$ was the vertex genotype in $E_{1}$ whereas, $G_{5}$ was vertex genotype in $E_{2}$ and $E_{3}$, with the highest seed yield. From "ideal" view it was reported that genotype $\mathrm{G}_{5}$ was the next to the ideal genotype, followed by $\mathrm{G}_{6}$ and $\mathrm{G}_{3}$, respectively. With regard to the environments, $\mathrm{E}_{3}$ was the most discriminating as well as the most typical environment. The stable production of amaranths is possible in favorable environment $E_{2}$ as it was positioned close to $\mathrm{E}_{3}$. Hence, it was concluded that GGE biplot could be efficiently used to predict stable and high yielding genotypes as well as best performing environments for the cultivation of amaranth.

\section{Acknowledgement}

All the authors would like to thank the authorities of S. D. Agricultural University, Sardarkrushinagar, India, for providing facilities for the successful completion of the research work.

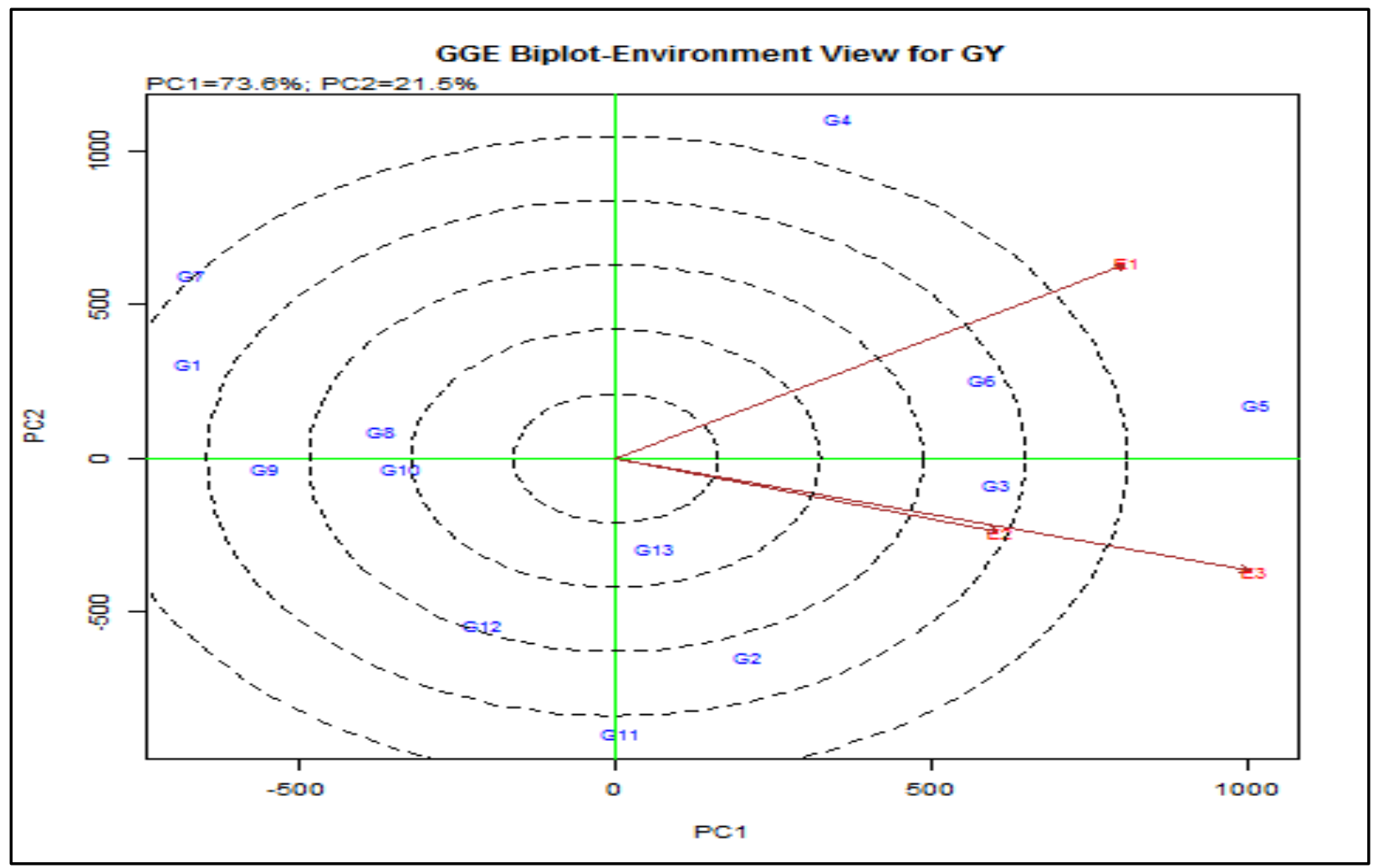

Figure $6 \mathrm{~A}$ genotype $+\mathrm{G} \times \mathrm{E}$ interaction biplot showing relationships among three environments. 


\section{Conflict of interest}

Authors would hereby like to declare that there is no conflict of interests that could possibly arise.

\section{References}

Balestre M, Souza JC, Pinho RGV, Oliveira RL, Paes JMV (2009) Yield stability and adaptability of maize hybrids based on GGE biplot analysis characteristics. Crop Breeding and Applied Biotechnology 9: 219-228.

Beyene Y, Mugo S, Mutinda C, Tefera T, Karaya H, Ajanga S, Shuma J, Tende R, Kega V (2011) Genotype by environment interactions and yield stability of stem borer resistant maize hybrids in Kenya. African Journal of Biotechnology 10 : 4752-4758.

Boshev D, Jankulovska M, Ivanovska S, Jankulosk IL, KuzManovska B, Tanaskovic V (2014) Evaluation of maize hybrids for grain yield stability under rainfed and irrigated conditions using GGE biplot analysis. Bulgarian Journal of Agricultural Science 20: 1320-1325. DOI: 10.4236/ajps.2014.511180

Bressani R (1989) The proteins of grain amaranth. Food Reviews International 5: 13-38.

Dehghani H, Ebadi A, Yousefi A (2006) Biplot analysis of genotype by environment interaction for barley yield in Iran. Agronony Journal 98: 388-393. DOI: 10.2134/agronj2004.0310

Dehghani H, Sabaghnia N, Moghaddam M (2009) Interpretation of genotype by environment interaction for late maize hybrids' grain yield using a biplot method. Turkish Journal of Agriculture and Forestry 33: 139-148. DOI:10.3906/tar-0712-25

Eberhart SA, Russell WL (1966) Stability parameters for comparing varieties. Crop Science 6: 36-40. DOI:10.2135/cropsci1966.0011183X000600010011x

Hebert Y, Plomion C, Harzic N (1995) Genotypic × environment interaction for root traits in maize as analysed with factorial regression models. Euphytica 81: 85-92.

Ilker E, Tonk FA, Caylak O, Tosun M, Ozmen I (2009) Assessment of genotype $\times$ environment interactions for grain yield in maize hybrids using AMMI and GGE biplot analyses. Turkish Journal of Field Crops 14: 123-135.

Kadoshnikov SI, Serge I, Kadoshnikova, IG, Martirosyan DM (2005) Investigation of fractional composition of the protein in amaranth. In: Non-traditional natural resources, innovation technologies and products, Russian Academy of Natural Sciences, Moscow, Pp. 81- 104.

Khalil IA, Rahman H, Rehman NU, Arif M, Khalil IH, Iqbal M, Ullah H, Afridi K, Sajjad M, Ishaq M (2011) Evaluation of maize hybrids for grain yield stability in North West of Pakistan. Sarhad Journal Agriculture 27: 213-218.

Miah MA, Rasul MG, Mian MAK, Rohman MM (2015) Evaluation of rapeseed lines for seed yield stability. International Journal of Agronomy and Agricultural Research 7: 12-19.

Mortazavian SMM, Nikkhah HR, Hassani FA, Sharif-al-Hosseini M, Taheri M, Mahlooji M (2014) GGE Biplot and AMMI analysis of yield performance of barley genotypes across different environments in Iran. Journal of Agricultural Science and Technology 16: 609-622.

Nzuve F, Githiri S, Mukunya DM, Gethi J (2013) Analysis of genotype $\times$ environment interaction for grain yield in maize hybrids. Journal of Agricultural Science 5: 75-85. DOI: http://dx.doi.org/10.5539/jas.v5n11p75

Oliveira RL, Garcia R, Von Pinho RG, Balestre M, Ferreira DV (2010) Evaluation of maize hybrids and environmental stratification by the methods AMMI and GGE biplot. Crop Breeding and Applied Biotechnology10: 247-253. DOI: http://dx.doi.org/10.1590/S1984-70332010000300010

Patel KS, Parihar A, Chaurasia P, Patel PJ, Pachchigar K (2014) Molecular characterization in grain amanranthus (Amaranthus spp.) using RAPD marker. Research Journal of Biotechnology 9: 29-35.

PB Tools, version 1.4. (2014) Biometrics and Breeding Informatics, PBGB Division, International Rice Research Institute. Los Baños, Laguna.

Rastogi A, Mishra BK, Srivastava M, Siddiqui A, Shukla S (2011) Biplot approach for identification of heterotic crosses in linseed (Linum usitatissimum L.).Journal of Botany Pp. 1-7.DOI: http://dx.doi.org/10.1155/2011/353102

Sabaghnia DNH, Sabaghpour SH (2008) Graphic analysis of genotype $\times$ environment interaction of lentil yield in Iran. Agronomy Journal 100: 760-764.

Samonte SOP, Wilson LT, Mc Clung AM, Medley JC (2005) Targeting cultivars onto rice growing environments using AMMI and SREG GGE biplot analysis. Crop Science 45: 2414-2424. Doi:10.2134/agronj2006.0282

Sauer JD (1967) The grain amaranths and their relatives: a revised taxonomic and geographic survey. Annals of the Missouri Botanical Garden 54: 103-137.DOI: 10.2307/2394998

Tonk FA, Ilker E, Tosun M (2011) Evaluation of genotype $\times$ environment interactions in maize hybrids using GGE biplot analysis. Crop Breeding and Applied Biotechnology11: 19.doi.org/10.1590/S1984-70332011000100001

Yan W (2001) GGE biplot-A windows application for graphical analysis of multi-environment trial data and other types of two- 
way data. Agronomy Journal 93: 1111-1118 doi:10.2134/agronj2001.9351111x

Yan W, Hunt LA, Sheng Q, Szlavnics Z (2000) Cultivar evaluation and mega-environment investigation based on the GGE biplot. Crop Science 40: 597-605.doi:10.2135/cropsci2000.403597x

Yan W, Kang MS (2002) GGE biplot analysis: A graphical tool for breeders, geneticists, and agronomists. CRC press.

Yan W, Kang MS (2003) GGE biplot analysis: a graphical tool for breeders, geneticists and agronomists. CRC Press, Boca Raton, FL.

Yan W, Kang MS, Ma B, Woods S, Cornelius PL (2007) GGE biplot vs. AMMI analysis of genotype by environment data. Crop Science 47: 643-655. doi:10.2135/cropsci2006.06.0374 